\title{
Menuju Bimbingan Konseling Islami
}

\author{
Hasan Bastomi \\ STAIN Kudus, Jawa Tengah, Indonesia \\ tommy.wedung@gmail.com
}

\begin{abstract}
Abstrak
Kecemerlangan ilmu pengetahuan dan teknologi pada zaman modern memang membawa kemajuan yang luar biasa. Namun seiring dengan itu semakin terkotak-nya antara sains dan agama yang mengakibatkan ditinggalkannya nilai-nilai moral dan etika. Tulisan ini mencoba menggali bagaimana reposisi Bimbingan Konseling Islam dalam sebuah keilmuan. Pada dataran teori, psikologi konseling memiliki empat grand theories, yaitu psikoanalisis, behavioristik, humanistik dan transpersonal. Maka kiranya perlu Konseling Islam bergerak menjadi mazhab kelima dari disiplin psikologi dengan cara mengembalikan paradigma ilmuwan kepada orientasi dunia dan akhirat. Karena sejatinya Fitrah manusia diciptakan mempunyai naluri beragama yaitu agama tauhid. Dalam hal ini perlu ditekankan kajian keagamaan, baik hal itu berasal dari perspektif Indigenous Counseling yang cross cultural dan mengungkap variabel budaya lokal maupun Konseling Agama itu sendiri terhadap pembentukan karakter individu. Bisa dilihat dari konteks sejarah konseling agama yang dijumpai pada zaman klasik Islam dikenal dengan nama hisbah. Maka perlu melakukan pengembangan Bimbingan Konseling Islami yaitu Proses pemberian bantuan terhadap individu sesuai asas yang pelaksanaan, agar mampu hidup selaras dengan ketentuan dan petunjuk Allah, sehingga dapat mencapai kebahagiaan hidup di dunia dan di akhirat.
\end{abstract}

Kata Kunci: Bimbingan Konseling, Islami

\begin{abstract}
The brilliance of science and technology in modern era has brought tremendous progress. But along with it increasingly compartmentalized between science and religion which resulted in the abandonment of moral and ethical values. This paper tries to explore how to reposition Islamic Counseling
\end{abstract}




\section{Hasan Bastomi}

Guidance in science. At the theoretical level, counseling psychology has four grand theories, namely psychoanalysis, behavioristic, humanistic and transpersonal. So it would be necessary for Islamic Counseling to move into the fifth school of psychological discipline by restoring the paradigm of scientists to the orientation of the world and the hereafter. Because the true nature of human beings are created to have religious instinct namely the religion of monotheism. In this case, it is necessary to emphasize religious studies, whether it comes from the perspective of cross cultural Indigenous Counseling and reveals local cultural variables and Religious Counseling itself towards the formation of individual characters. It can be seen from the historical context of religious counseling found in the classical period of Islam known as hisbah. Then it is necessary to develop Islamic Counseling Guidance, namely the process of providing assistance to individuals in accordance with the principles of implementation, so that they are able to live in harmony with God's provisions and instructions, so that they can achieve happiness in the world and in the hereafter.

Keyword: Counseling Guidance, Islami

\section{A. Pendahuluan}

Kecemerlangan ilmu pengetahuan dan teknologi pada zaman modern memang membawa kemajuan yang luar biasa. Pada lima atau enam dasawarsa terakhir, diskursus tentang kritik terhadap ilmu pengetahuan modern dipandang telah menghasilkan buah yang pahit. Disebut demikian, karena epistimologi ilmu yang digunakan terlampau rasionalistik. Ilmu yang terlampau rasionalistik pada bagiannya akan menjadikan manusia jauh dari nila-nilai agama. Sebagaimana disinyalir oleh Fritjof Capra dalam The Turning Point : Science, Society, and The Rising Culture, bahwa ilmu pengetahuan modern telah terlepas dari nilai-nilai agama (Bastaman, 2001: 8).

Munculnya kritik terhadap ilmu pengetahuan modern bukan hanya terjadi di dunia Barat, tetapi juga di dunia Islam. Salah satu gerakan yang mengedepankan gerakan setelah diproklamirkan kebangkitan Islam di abad XV Hijriah pada tahun 1970-an adalah Islamisasi ilmu (Ancok, 1996: ix). Gagasan yang dimotori oleh Ismail 


\section{Menuju Bimbingan Konseling Islami}

Raji Al-Faruqi (1921-1986) dan Sayyed M. Naquib Al-Attas ini, tampaknya mendapat tanggapan yang sangat positif, diberbagai belahan dunia Islam.

Yang menarik dari gagasan Ismail Raji Al-Faruqi (1921-1986) adalah bahwa usaha Islamisasi mesti ada penguasaan yang cukup komprehensif antara khazanah kelimuan modern dan khazanah keilmuan Islam klasik, ilmuwan muslim mesti kritis terhadap ilmuilmu yang dikembangkan Barat, dan kemudian melakukan sebuah integralisasi keduanya. Hal ini ditujukan untuk mendapatkan sebuah model penguasaan ilmu dengan perspektif Islam dan pengetahuan modern yang ada. Dari situlah kemudian akan menghasilkan model kurikulum dan pendidikan dalam perspektif Islam. Dan inilah yang menjadi Ultimate Goal gagasan Islamisasi pengetahuan ala Al-Faruqi (1921-1986) (Al-Faruqi, 1982: 83).

Paling tidak ada dua alasan yang mendorong ilmuwan muslim melaksanakan islamisasi sains. Pertama, semakin terkotaknya antara sains dan agama yang mengakibatkan ditinggalkannya nilai-nilai moral dan etika. Ini terlihat dari semakin majunya peradaban suatu negara karena kemnajuan sains, ternyata membawa dampak berbagai kerawanan sosial dan psikologis. Meskipun saat ini ada beberapa kalangagn ilmuwan Barat sendiri mulai melirik kembali untuk memperhatikan agama dalam sains, tetapi arus utama mereka masih belum bergeming dari posisi semula, yang mengganggap agama sebagai bagian masa lalu sains yang saat ini harus ditinggalkan.

Alasan kedua adalah keinginan ilmuwan muslim untuk melihat kembali kejayaan ilmuwan muslim seperti pada abad pertengahan setelah mentransfer berbagai bentuk pengetahun dari budaya Yunani dan Romawi. Meskipun tidak persis sama, tetapi situasi yang dihadapi oleh ilmuwaan di dunia muslim saat ini tampaknya mirip dengna situasi umat Islam di abad pertengahan itu. Ini bukanlah sekedar utopia ilmuwan muslim yang sedang dalam posisi underdog, tetapi secara obyektif hal ini juga diakui oleh ilmuwan Barat sendiri. Bahkan beberapa ilmuwan memprediksikan akan adanya perseteruan dan pertempuran kebudayaan (setelah perseteruan antara dua super-power dunia), yaitu pertentangan 
antara budaya Barat dan budaya Islam, yang salah satu di antaranya adalah di bidang ilmu pengetahun (Subandi, 2005: 2).

Menarik diperhatikan, ternyata semangat untuk memberi muatan Islam terhadap ilmu pengetahuan juga mendapat tanggapan dari ilmuwan muslim psikologi. Wacana psikologi Islami (Nashori, 2010: 6) mulai bergaung semenjak tahun 1978. Pada tahun itu, di Universitas Riyald, Arab Saudi, berlangsung simposium internasional tentang psikologi dan Islam (Internatioal Symposium On Psychology and Islam). Sebelum kegiatan Internasional ini, pada tahun 1975, The Association Of Muslim Social Scientist (AMMS) Amerika dan Kanada memberikan kesempatan kepada Malik B. Badri untuk membentangkan pemikirannya dalam forum yang mereka selenggarakan. Pemikiran Malik B. Badri yang disampaikan dalam kegiatan AMMS tersebut dituangkan dalam sebuah makalah yang berjudul Psikolog Muslim dalam Liang Biawak (Badri, 1994: 1). Setahun sesudahnya 1979, di Inggris terbit sebuah buku yang sangat momumental di dunia Islam, yaitu The Dilema Of Muslim Psychologist yang ditulis Malik B. Badri, dalam pertemuan ilmuwan Internasional dan penerbitan buku ini memberikan inspirasi bagi lahir dan berkembangnya wacana psikologi Islami. Dalam karya-karya Idries Shah seperti Learning How To Learn: Psychology And Spirituality In The Sufi Way, The Sufis, dll, menunjukkan bahwa konsep sufi tradisional dapat memecahkan persoalan sosial, psikologis, dan spiritual manusia (Shah, 2002: 19) . Tidak jauh dari Idries Shah, Inayat Khan dalam karyanya The Spiritual Dimensions of Psychology berupaya mempertemukan berbagai disiplin ilmu jasmaniah (material) dengan ilmu ruhaniah (spiritual) (Khan, 2000: 13-14). Ilmuan yang secara khusus mengkaji tasawuf dan psikologi adalah Javad Nurbakhsyi dalam karyanya Psychology of Sufism, yang sepenuhnya menggunakan perspektif spiritual untuk memetakan kondisi kejiwaan manusia (Nurbakhsy, 1992: 64).

Salah satu ilmu yang menjadikan psikologi sebagai pijakan pelaksanaan adalah konseling. Diantara berbagai disiplin ilmu, yang memiliki kedekatan hubungan dengan konseling adalah psikologi, bahkan secara khusus dapat dikatakan bahwa konseling merupakan aplikasi dari psikologi, terutama jika dilihat dari tujuan, teori yang digunakan, dan proses penyelenggaraannya. Oleh karena itu telaah 


\section{Menuju Bimbingan Konseling Islami}

mengenai konseling dapat disebut dengan psikologi konseling (counseling psychology). Dilihat dari proses konseling, Psikologi konseling adalah cabang kekhususan dari psikologi yang mengkaji berbagai aspek yang terlibat dalam proses konseling. Aspek-aspek itu meliputi karakteristik; konseling, konselor, konseli dan masalahnya, berbagai kondisi yang menunjang dan menghambat konseling, serta metode atau pendekatan-pendekatan dalam konseling.

Didalam proses konseling, semua aspek tersebut saling terkait. Sehingga tidak dapat dilepaskan satu sama lain. Seorang konselor professional akan lebih berhasil dalam memberikan pelayanan konseling kepada konselinya. Keprofesionalan seorang konselor didukung oleh pemahaman psikologinya yang luas. Karena dengan pemahaman terhadap Psikologi akan sangat membantu seorang konselor dalam memahami tingkah laku dan proses mental dari seorang klien. Tanpa psikologi maka ia tidak akan mampu menciptakan suasana konseling yang efektif. Karena didalam proses konseling konselor diharapkan mampu untuk memanfaatkan segala kondisi yang menunjang kesuksesan proses konseling dan menghindari faktor-faktor yang dapat menghambat konseling.

Semangat untuk memberi muatan Islam terhadap ilmu pengetahuan juga mendapat tanggapan dari ilmuwan muslim dalam konseling. Dalam Q.S Al-Isra ayat 26 menjelakan bahwa sesama manusia harus saling peduli. Ini adalah salah satu dasar Al-Quran yang menjadi landasan konseling untnuk memberikan bantuan terhadap seseorang yang sedang menghadapi masalah. Sedangkan yang dimaksud dengan Konseling Islam adalah proses pemberian bantuan terhadap individu, agar menyadari kembali akan eksistensinya sebagai makhluk Allah yang seharusnya selaras dengan ketentuan dan petunjuk Allah, sehingga dapat mencapai kebahagiaan di dunia dan di akhirat (Musnamar, 1992: 5).

Salah satu gerakan budaya Islam di bidang ilmu pengetahuan adalah munculnya Konseling Islami. Tulisan ini mencoba membahas posisi gerakan konseling Islami dalam konteks perkembangan ilmu pengetahuan. 


\section{B. Pembahasan}

\section{Telaah kritis terhadap konseling barat}

Sebagai dasar dari pelaksanaan konseling psikologi merupakan disiplin ilmu yang mempelajari aspek-aspek kejiwaan yang mencakup proses mental dan perilaku manusia. Apabila ilmuwan membahas tentang apa itu manusia, bagaimana cara mengetahui perilaku manusia, dan apa manfaat dari proses pengkajian perilaku manusia tersebut, seharusnya psikologi mampu memaparkan secara ilmiah. Hal itu perlu ditekankan agar sesuai dengan kaidah Filsafat Ilmu suatu disiplin ilmu pengetahuan, yaitu Ontologi, Epistemologi, dan Aksiologi disiplin ilmu. Setelah pemaparan tiga unsur keilmuan tersebut bisa dijadikan landasan utama konseling untuk menentukan lima tugas utama sebagai disiplin ilmu yang ilmiah, yaitu mampu menggambarkan unsur-unsur perilaku secara jelas, yaitu mampu menjelaskan (describing) apa, bagaimana, dan mengapa tingkah laku itu terjadi, mampu menerangkan (explaining) kondisi yang mendasari terjadinya peristiwa, menyusun teori, mencari dan merumuskan hukumhukum mengenai hubungan peristiwa satu dengan yang lainnya dalam dinamika perilaku, mampu memprediksi atau memperkirakan (predicting) dan mengestimasi hal-hal yang akan terjadi dari suatu perilaku tertentu, dan melakukan pengendalian (controlling) atau mengatur perilaku sesuai dengan yang diharapkan. Orientasi Perwujudan pada tugas psikologi konseling yang kelima tersebut adalah berupa tindakan atau treatment.

Secara umum, tinjauan historis itu perlu dikomparasikan dengan rentang kajian ilmu jiwa, perilaku, dan kesehatan mental yang sudah berlangsung sejak zaman Yunani Kuno. Sebut saja salah seorang filsuf Yunani pada zaman Hellenic, Plato. Plato pernah memfokuskan kajiannya pada human motivation. Plato mendefinisikan tiga tingkatan soul, yaitu sebagai berikut (Brennan, 1991): (1) Rational Soul : located in the head, the highest level, perfect. (2) Spirited Soul : located in the chest, noble things like glory and immortality of fame, capable of shame and guilt. (3) Desiring Soul: located in the belly and below: irrational impulses, such as food, sex, desire for money (Hidayat, 2014: 7-8). 


\section{Menuju Bimbingan Konseling Islami}

Setelah zaman Yunani Kuno itu, kajian sejarah psikologi konseling berkembang memasuki sampai abad ke-XIX era Wundt. Wilhelm Wundt (1832-1920) dilahirkan di Neckarau, Baden, Jerman, dari keluarga intelektual dipandang sebagai pendiri Psikologi secara ilmiah. Ia menamatkan studi kesarjanaannya dan memperoleh gelar doktor di bidang kedokteran dan tertarik pada riset-riset fisiologis. Ia melakukan penelitian di bidang psikofisik bersama-sama dengan Johannes Mueller an Hermann von Helmholtz. Karya utamanya pada masa-masa ini adalah Grundzuege der Physiologischen Psychologie (Principles of physiological psychology) pada tahun 1873-1874. Wundt memperoleh posisi sebagai professor dan mengajar di Universitas Leipzig dimana ia mendirikan Psychological Institute. Laboratorium psikologi didirikan pada tahun 1879, menandai berdirinya psikologi sebagai sebuah disiplin ilmu ilmiah. Setelah itu, berkembang lagi kelompok kajian psikologi konseling yang dikenal dengan aliran Fungsionalisme, Behaviorisme, Psikoanalisa, Psikologi Gestalt, Konseling Humanistik (Panggabean, 2009: 63).

Pada dataran teori, psikologi konseling memiliki empat grand theories, yaitu psikoanalisis, behavioristik, humanistik dan transpersonal. Teori psikoanalisis dikembangkan oleh Sigmund Freud, seorang psikiater dari Austria. Karena berkembagn dari latar belakang klinis, maka tidak heran jika teori psikoanalisis banyak menyoroti tentang sisi negatif manusia. Temuan-temuan Freud sebenarnya sangat penting. Misalnya teori tentang ketidaksadaran (unconsciousness), teori kepribadian (id, ego, superego) dan berbagai bentuk-bentuk mekanisme pertahanan diri merupakan hasil pemikiran luar biasa yang diakui ilmuwan Barat sebagai temuan tenting abad 20. Tetapi teori banyak menerima kritik dikalangan psikologi sendiri. Terutama pandangan Freud yang menganggap bahawa manusia pada dasarnya dikuasai oleh dua instink yang dominan yaitu sex dan agresi. Dengan teori ini Freud mencoba menjelasakan berbagai macam fenomena, mulai dari politik, ekonomi, sisial, budaya sampai pada fenomena-fenomena keagamaan.

Freud menganggap bahwa keyakinan-keyakinan dalam agama berakar dari ketakutan-ketakutan dan harapan-harapan pada masa kanak-kanak, khususnya berkaitan dengan oedipus complex. 
Tuhan menurut Freud merupakan penciptaan kembali dari omniscient dan omnipotent figur ayah pada masa kanak-kanak. Oleh karena itu para pemeluk agama pada umumnya mempunyai perasaan ambivalen, yaitu perasaan cinta dan takut terhadap Tuhan. Demikian juga Freud menganggap bahwa ibadah-ibadah ritual yang dilakukan berulangkali oleh para pemeluk agama, tidak lain merupakan suatu bentuk obsessive-compulsive. Akhirnya dikatakan bahwa agama tidak lain adalah sekedar ilusi yang menghambat manusia mencapai kedewasaan.

Teori kedua adalah Behaviorisme. Teori ini berkembang sebagai reaksi dari psikoanalisis yang sangata menekankan pada ketidaksadaran dan masa lalu. Aliran ini beranggapan bahwa yang paling menentukan adalah kondisi lingkungan upaya rekayasa perilaku. Teori ini melihat bahwa pada dasarnya manusia itu netral. Baik buruknya perilaku sangata ditentukan oleh responnya terhadap stimulus dari lingkungan. Jadi pada dasarnya manusia hanya memiliki kemampuan merespon terhadap berbagai stimulus saja. Teori-teori mazhab behavioristik ini dikembangkan dari hasil eksperimen perilaku binatang di laboratorium yang terkontrol ketat.

Prinsip psikologi konseling behovioristik lain yang banyak digunakan dalam proses belajar adalah prinsip reward and punishment, the law of effect, maupun teori modelling. Prinsip-prinsip ini saat ini banyak diterapkan dalam berbagfai bentuk teknik-teknik perubahan perilaku. Kritik yang banyak dilontarkan pada aliran ini adalah pandangannnya yang melihat manusia sebagai produk respon terhadap lingkungan yang mengimplikasikan bahwa manusia tidak lain seperti mesin robot yang bereaksi jika mendapat stimulus, tanpa memiliki kemampuan untuk menentukan dirinya sendiri.

Sebagai reaksi terhadap dominasi psikologi konseling behavioristik, maka muncullah aliran ketiga, Psikologi konseling Humanistik. Aliran ini melihat bahwa manusai memiliki harkat kemanusiaan. Kualitas insani yang baik secara inheren terpateri dalam diri manusia. Misalnya rasa tanggungjawab, kebebasan berkehendak, memahami makna hidup, kreativitas, aktualisasi diri, sikap etis dan estetis. Kualitas ini hanya dimiliki oleh mahluk yang namanya manusia saja. Berbeda dengan psikoanalisis yang berorientasi masa lalu dan behaviorsitik yang berorientasi masa kini, 


\section{Menuju Bimbingan Konseling Islami}

maka psikologi humanistik melihat bahwa masa depan sangat menentukan perilaku masnusia. Orang yang meyakini bahwa dimasa depan dia harus bertanggungjwab terhadap setiap perilakunya, maka dalam bertindak dia akan selalu penuh pertimbangan.

Aliran Psikologi Konseling Humanistik ini sangat memperhatikan dimensi spiritual manusia. Bahkan secara khusus psikologi Humanistik telah merangsang timbulnya satu aliran baru yang secara khusus mengkaji fenomena-fenomena spiritualitas, yaitu Psikologi Transpersonal. Aliran terakhir ini melihat bahwa manusia memiliki suatu potensi kesadaran yang disebut altered states of consciousness yang dapat menjangkau alam keruhanian. Aliran teraskhir ini telah memberi peluang bagi munculnya sebuah psikologi baru yang berwawasan agama (Subandi, 2005: 4-6).

Berbeda dengan pembagian mazhab atau aliran psikologi konseling di atas, Abraham Maslow membagi empat mazhab besar disiplin Psikologi konseling, yaitu Psikoanalisa, Behaviorisme, Humanisme, dan Psikologi Transpersonal. Pembagian empat mazhab itu juga masih memiliki kelemahan, yaitu tidak memasukkan peran agama secara signifikan ke dalam disiplin konseling. Apalagi jika memperhatikan pendapat ilmuwan positivistik yang cenderung memisahkan agama dan ilmu pengetahuan. Padahal, kepribadian individu yang terbentuk dari unsur bio-psiko-spiritual sangat dipengaruhi oleh agama. Jadi tak mengherankan jika ahli Konseling Islam mengatakan bahwa Konseling Islam akan bergerak menjadi mazhab kelima dari disiplin psikologi dengan cara mengembalikan paradigma ilmuwan kepada orientasi dunia dan akhirat.

Oleh karena itu, perlu ditekankan kajian keagamaan, baik hal itu berasal dari perspektif Indigenous Counseling yang cross cultural dan mengungkap variabel budaya lokal maupun Konseling Agama itu sendiri terhadap pembentukan karakter individu. Hal itu dipandang penting agar bisa mencapai tujuan kelima dari disiplin ilmu konseling, yaitu konseling mampu melakukan pengendalian (controlling) atau mengatur perilaku sesuai dengan yang diharapkan berdasarkan karakteristik individu yang dipengaruhi oleh faktor budaya dan agama. Orientasi perwujudannya adalah pada tugas konseling yang kelima tersebut, yaitu berupa tindakan pertolongan 
konseling atau treatment sesuai dengan latar belakang budaya dan agama seseorang (Hidayat, 2014: 8).

\section{Agama dan Jiwa Manusia}

Agama merupakan hal yang tidak dapat dipisahkan dari kehidupan manusia. Hubungan manusia dengan agama tampaknya merupakan hubungan yang bersifat kodrati. Agama itu sendiri menyatu dalam fitrah penciptaan manusia. Terwujud dalam bentuk ketundukan, kerinduan ibadah, serta sifat-sifat luhur. Manakala dalam menjalankan kehidupannya, manusia menyimpang dari nilainilai fitrahnya, maka secara psikologis ia akan merasa adanya semacam "hukuman moral". Lalu spontan akan muncul rasa bersalah atau rasa berdosa (sense of guilty).

Psikologi modern tampaknya memberi porsi yang khusus bagi perilaku keagamaan, walaupun pendekatan psikologis yang digunakan terbatas pada pengalaman empiris. Psikologi agama merupakan salah satu bukti adanya perhatian khusus para ahli psikologi terhadap peran agama dalam kehidupan kejiwaan manusia.

Pendapat yang paling ekstrem pun hal itu masih menunjukkan betapa agama sudah dinilai sebagai bagian dari kehidupan pribadi manusia yang erat kaitannya dengan gejala-gejala psikologi. Agama menurut Freud tampak dalam perilaku manusia sebagai simbolisasi dari kebencian terhadap Ayah yang direfleksi dalam bentuk tasa takut kepada Tuhan. Secara psikologis, agama adalah ilusi manusia. Manusia lari kepada agama karena rasa ketidak- berdayaannya menghadapi bencana. Dengan demikian, segala bentuk perilaku keagamaan merupakan ciptaan manusia yang timbul dari dorongan agar dirinya terhindar dari bahaya dan dapat memberikan rasa aman.

Lain halnya dengan penganut Behaviorisme. Sejalan dengan prinsip teorinya, bahwa Behaviorisme memandang perilaku manusia itu lahir karena adanya stimulant (rangsangan dari luar dirinya) teori Sarbond (gabungan dari stimulant dan respon) yang dikemukakan oleh Behaviorisme tampaknya memang kurang memberi tempat bagi kajian kejiwaan nonfisik. Namun, dalam masalah perilaku 


\section{Menuju Bimbingan Konseling Islami}

keagamaan, sebagai sebuah realitas dalam kehidupan manusia tak mampu ditampik oleh Behaviorisme. Perilaku keagamaan menurut pandangan Behaviorisme erat kaitannya dengan prinsip reinforcement (reward and punishment). Manusia berperilaku agama karena didorong oleh rangsangan hukuman dan hadiah. Menghindarkan hukuman (siksaan) dan mengharapkan hadiah (pahala) (Jalaluddin, 2010: 159-160).

Agama memang tidak dapat dipisahkan dari kehidupan manusia. Pengingkaran manusia terhadap agama mungkin karena faktor-faktor tertentu baik yang disebabkan oleh kepribadian maupun lingkungan masing-masing, namun untuk menutupi atau meniadakan sama sekali dorongan dan rasa keagamaan tampaknya sulit dilakukan, hal ini karena manusia memiliki unsur batin yang cendrung mendorongnya untuk tunduk kepada zat yang ghaib. Ketundukan ini merupakan bagian dari faktor intern manusia yang dalam psikologi kepribadian dinamakan pribadi (self) ataupun hati nurani (consience of man).

Agama sebagai fitrah manusia telah diinformasikan oleh AlQuran. Fitrah manusia sebagai makhluk ciptaan Allah SWT ialah manusia diciptakan mempunyai naluri beragama yaitu agama tauhid. Kalau ada manusia tidak beragama tauhid, maka tidak wajar, mereka tidak beragama tauhid itu hanya karena pengaruh lingkungan, seperti yang ada dalam QS.Ar Rum:30-31 (Jalaluddin, 2010: 165).

Hubungan antara agama sebagai keyakinan dan kesehatan jiwa, terletak pada sikap penyerahan diri seseorang terhadap suatu kekuasaan Yang Maha Tinggi. Sikap tersebut akan memberikan sikap optimis pada diri seseorang sehingga muncul perasaan positif seperti rasa bahagia, puas, sukses, merasa dicintai, atau merasa aman. Sikap emosi yang demikian merupakan bagian dari kebutuhan hak asasi manusia sebagai makhluk yang ber-Tuhan. Maka dalam kondisi tersebut manusia berada dalam keadaan tenang dan normal.

Cukup logis bahwa ajaran agama mewajibkan penganutnya untuk melaksanakan ajrannya secara rutin. Bentuk dan pelaksanaan ibadah agama, paling tidak akan dapat berpengaruh dalam menanamkan keluhuran budi yang pada puncaknya akan menimbulkan rasa sukses sebagai pengabdi tuhan yan setia. Tindak ibadah setidak-tidaknya akan memberi rasa bahwa hidup menjadi 
lebih bermakna. Manusia sebagai makhluk yang memiliki kesatuan jasmani dan rohani secara tak terpisahkan memerlukan perlakuan yang dapat memuaskan keduanya (Jalaluddin, 2010: 170-172).

Salah satu cabang ilmu jiwa, yang tergolong dalam psikologi humanistika dikenal logoterapi (logos berarti makna dan juga rohani). Logoterapi dilandasi falsafah hidup dan wawasan mengenai manusia yang mengakui adanya dimensi sosial pada kehidupan manusia. kemudian, logoterapi menitikberatkan pada pemahaman bahwa dambaan utama manusia yang asasi atau motif dasar manusia adalah hasrat untuk hidup bermakna. Diantara hasrat itu terungkap dalam keinginan manusia untuk memiliki kebebasan dalam menemukan makna hidup. Kebebasan seperti itu dilakukannya antara lain melalui karya-karya yang diciptakannya, hal-hal yang dialami dan dihayati (termasuk agama dan cinta kasih) atau dalam sikap atas keadaan dan penderitaan yang tak mungkin dielakkan. Adapun makna hidup adalah hal-hal yang memberikan nilai khusus bagi seseorang, yang bila dipenuhi akan menjadikan hidupnya berharga dan akhirnya akan menimbulkan penghayatan bahagia. Dalam logoterapi dikenal dua peringkat makna hidup, yaitu makna hidup pribadi dan makna hidup paripurna.

Maka hidup paripurna bersifat mutlak dam universal, serta dapat saja dijadikan landasan dan sumber makna hidup pribadi. Bagi mereka yang tidak atau kurang penghayatannya terhadap agama, mungkin saja pandangan falsafah atau ideology tertentu dianggap memiliki nilai-nilai universal dan paripurna. Sedangkan bagi penganut agama, maka Tuhan merupakan sumber nilai Yang Maha Sempurna dengan agama sebagai perwujudan tuntutan-Nya. Di sinilah barangkali letak peranan agama dalam membina kesehatan mental, berdasarkan pendekatan logoterapi. Karena bagaimanapun, suatu ketika dalam kondisi yang berada dalam keadaan tanpa daya, manusia akan kehilangan pegangan dan bersikap pasrah. Dalam kondisi yang serupa ini ajaran agama paling tidak akan membangkitkan makna dalam hidupnya. Makna hidup pribadi menurut logoterapi hanya dapat dan harus ditemukan sendiri.

Selanjutnya, logoterapi menunjukkan tiga bidang kegiatan yang secara potensial memberi peluang kepada seseorang untuk menemukan makna hidup bagi dirinya sendiri. ketiga itu adalah: (1) 


\section{Menuju Bimbingan Konseling Islami}

Kegiatan berkarya, bekerja, dan mencipta, serta melaksanakan dengan sebaik-baiknya tugas dan kewajiban masing-masing. (2) Keyakinan dan penghayatan atas nilai-nilai tertentu (kebenaran, keindahan, kebaikan, keimanan,n dan lainnya), dan (3) Sikap tepat yang diambil dalam keadaan dan penderitaan yang tidak terelakkan.

Dalam menghadapi sikap yang tak terhidarkan lagi pada kondisi yang ketiga, menurut logoterapi, maka ibadah merupakan salah-satu cara yang dapat digunakan untuk membuka pandangan seseorang akan nilai-nilai potensial dan makna hidup yang terdapat dalam diri dan sekitarnya (Jalaluddin, 2010: 170-172).

Psikologi dan agama mempunyai keterkaitan yang sangat erat. Sebelum Psikologi Barat berkembang pada abad 19, agama menjadi reference pokok dalam menafsirkan maupun sebagai solusi persoalan kejiwaan. Mislanya berkembangnya Moral Theraphy di Inggris sebagai terapi bagi penderita gangguan jiwa.

Di awal perkembangan Psikologi Konseling fenomena agama menjadi kajian yang cukup penting, yang kemudian melahirkan displin psikologi agama. Salah satu pusat pengembangan psikologi agama adalah di Clark University yang dipimpin oleh G. Stanley Hall, yang juga dikenal sebagai pendiri psikologi Barat (Subandi, 2002, 185). Di Universitas ini berbagai fenomena keagamaan seperti Konversi agama, pengalaman keberagamaan, proses perkembangan keagamaan banyak dikaji. Disiplin ini sempat vakum ketika aliran behaviorisme menguasai Barat, tetapi sekarang mengalami revitalisasi kembali. Bersamaan dengan itu kesadaran para ilmuwan (baca: psikolog) terhadap pentingnya faktor keagamaan (religiusitas) dan spiritualitas berkembang dengan pesat, sehingga American Psychological Association (APA) harus membentuk satu komisi khusus yang menampung para psikolog yang berminat pada bidang kajian keagamaan dan spiritualitas.

Pada waktu yang bersamaan muncul berbagai bentuk konseling yang dikembangkan berdasarkan satu denominasi agama tertentu. Sejak tahun 1960-an para konseling yang beragama Hindu telah mencoba menggali suatu bentuk Hindu Counseling (Sivananda, 1946), demikian juga ilmuwan yang tertarik pada ajaran Budha, mengembangkan Buddhist Counseling (Sattipathana). Ilmuwan Yahudi mengembangkan Jewish Counseling. Sebagai agama yang 
dominan di Barat, psikolog Kristen telah mengembangkan berbagai bentuk Christian Counseling (Counseling Pastoral). Misalnya penerbitan jurnal Counseling and Christianity dan bentuk aplikasi Pastoral Counseling. (Subandi, 2005: 6-7). Wacana Islamic Counseling di dalam blantika konseling modern masih belum banyak dikenal. Dilihat dari proses ini, kehadiran Konseling Islami boleh dikata agak tertinggal dibandingkan dengan konseling yang berwawasan religius di atas.

\section{Konseling Islami}

Konseling Agama dalam Tradisi Islam Klasik Menurut Kamal Ibrahim Mursi, aktifitas konseling agama yang dijumpai pada zaman klasik Islam dikenal dengan nama hisbah, atau ihtisab, konselornya disebut muhtasib, dan klien dari hisbah tersebut dinamakan muhtasabalaih. Pengertian hisbahHisbah menurut pengertian syara' artinya menyuruh orang (klien) untuk melakukan perbuatan baik yang jelas-jelas ia tinggalkan, dan mencegah perbuatan munkar yang jelas-jelas dikerjakan oleh klien (amar ma'ruf nahi munkar) serta mendamaikan klien yang bermusuhan. Hisbah merupakan panggilan, oleh karena itu muhtasib melakukannya semata-mata karena Allah, yakni membantu orang agar dapat mengerjakan hal-hal yang menumbuhkan kesehatan fisik, mental dan sosial, dan menjauhkan mereka dari perbuatan yang merusak.

Bentuk amar ma'ruf dalam hisbah ialah menyuruh dan menghendaki kliennya mengerjakan yang ma'ruf, yakni semua hal yang dituntut syara, termasuk perbuatan dan perkataan yang membawa kemaslahatan bagi individu dan masyarakat, yang wajib maupun yang sunat. Sedangkan bentuk nahi munkar dalam hisbah ialah meminta klien menjauhi yang munkar, yakni semua yang dilarang syara', termasuk perbuatan dan perkataan yang mendatangkan kesulitan bagi pribadi dan masyarakat.

Sudah barang tentu hisbah dilakukan dengan prinsip suka sama suka, bersifat sugesti dan introspeksi, sehingga klien menyadari betul manfaat perbuatan ma'ruf dan bahayanya perbuatan munkar, dan dengan itu klien terdorong pada perbuatan baik dan allergi terhadap yang mungkar, kuat motivasi positipnya dan padam motivasi negatipnya. Hisbah juga dilakukan dengan lemah lembut. 


\section{Menuju Bimbingan Konseling Islami}

Nabi pernah mencontohkan bagaimana menanamkan suatu pengertian kepada orang yang memang belum memiliki pengertian tentang suatu kebaikan dan kemunkaran artinya: Seorang pemuda mendatangi Rasul dan bertanya secara lantang di hadapan orang banyak; Wahai Nabi Allah, apakah engkau dapat mengizinkan aku untuk berzina? Mendengar pertanyaan yang tidak sopan itu orangorang ribut mau memukulinya, tetapi Nabi segera melarang dan memanggil, Bawalah pemuda itu dekat-dekat padaku. Setelah pemuda itu duduk di dekat Nabi, maka Nabi dengan santun bertanya kepada pemuda itu: Bagaimana jika ada orang yang akan menzinahi ibumu? Demi Allah aku tidak akan membiarkannya, kata pemuda itu. Nabipun meneruskan, nah begitu pula orang tidak akan membiarkan hal itu terjadi pada ibu mereka. Bagaimana jika terhadap anak perempuanmu? Tidak, demi Allah, aku tidak akan membiarkannya, kata pemuda itu. Nabi melanjutkan, bagaimana jika terhadap saudara perempuanmu? Tidak juga, ya Rasul, Demi Allah aku tidak akan membiarkannya, kata si pemuda. Nabi meneruskan, Nah begitu juga orang tidak akan membiarkan putrinya atau saudara perempuanya atau bibinya dizinahi.

Nabi kemudian meletakkan tangannya ke dada pemuda itu sambil berdoa; Ya Allah bersihkanlah hati pemuda ini, ampunilah dosanya dan jagalah kemaluannya. (H.R. Ahmad dari Abu Umamah)Menurut parawi hadis tersebut, sejak peristiwa itu sang pemuda tidak lagi menengok kiri kanan untuk berbuat zina. Dalam hadis itu jelas digambarkan bahwa dalam menghadapi pemuda itu Nabi tidak menempatkan diri sebagai subyek yang melarang atau memberi nasehat, tetapi hanya mengantar sang pemuda untuk berfikir jernih tentang implikasi zina bagai orang lain, dan selanjutnya sang pemuda itulah yang harus menjadi subyek dirinya untuk memutuskan sendiri apa yang terbaik bagi dirinya. Secara psikologis, manusia memang satu-satunya makhluk yang bisa menjadi subyek dan obyek sekaligus. Tentang hukum hisbah, para fuqaha berbeda pendapat antara fardlu 'ain dan fardlu kifayah. Yang pertama mendasarkan pendapatnya pada firman Allah: Artinya: "dan orang-orang yang beriman, lelaki dan perempuan, sebahagian mereka (adalah) menjadi penolong bagi sebahagian yang lain. mereka menyuruh (mengerjakan) yang ma'ruf, mencegah dari yang munkar, 
mendirikan shalat, menunaikan zakat dan mereka taat pada Allah dan Rasul-Nya. mereka itu akan diberi rahmat oleh Allah; Sesungguhnya Allah Maha Perkasa lagi Maha Bijaksana." (Al Taubah: 71)

Khalifah Umar bin al Khattab adalah orang pertama yang mengatur pelaksanaan hisbah sebagai suatu sistem dengan merekrut dan mengorganisir muhtasib (konselor) dan kemudian menugaskan mereka ke segala pelosok kaum muslimin guna membantu orangorang yang bermasalah. Khalifah berikutnya juga meneruskan kebijaksanaan Umar, sehingga ketika itu jabatan muhtasib menjadi jabatan yang terhormat di mata masyarakat. Menurut Ibnu Khaldun, hisbah itu merupakan tugas keagamaan dalam bidang/amar makruf nahi munkar, yang merupakan kewajiban yang harus dijalankan oleh pemerintah (Mursi, 1981: 23-25). Bentuk-bentuk ihtisab/ hisbah ketika itu menurut Kamal Ibrahim Mursi antara lain:

\section{a. Pemberian nasehat (mau'idzah hasanah)}

Secara umum, yakni dilakukan secara perorangan atau kelompok, di masjid, di rumah atau di tempat kerja. Tahap ini sifatnya merupakan langkah prefentip.

\section{b. Bimbingan ringan secara individual}

Bentuk hisbah ini diberikan kepada orang-orang yang nyata nyata membutuhkan, diminta atau tidak diminta. Obyek bimbingannya bisa menyangkut masalah keagamaan, kerumah tangaan, kepribadian, pekerjaan dsb. Dalam menjalankan hisbah dalam bentuk ini, muhtasib (konselor) berusaha menjumpai muhtasab 'alaihi (klien) berdua saja. Bentuk hisbah ini dilakukan untuk mendorong motivasi klien pada kebaikan, dan mendorongnya alergi terhadap kemunkaran,dan menyadarkannya untuk menerima kenyataan secara ikhlas.

\section{c. Bimbingan berat secara individual}

Metode ini dilakukan terhadap orang yang sudah terang terangan menjalankan perbuatan tercela/keji, dan terang-terangan pula tidak mau mengerjakan perbuatan baik, orang yang sudah akrab dengan kejahatan dan allergi terhadap kebaikan. Orang pada tingkat seperti ini biasanya sudah tidak mempan terhadap nasehat-nasehat yang lemah lembut. Kepada orang semacam ini, muhtasib dalam percakapanya sengaja menggunakan kata-kata yang keras seraya 


\section{Menuju Bimbingan Konseling Islami}

mengingatkan resiko yang akan diterimanya di dunia maupun di akhirat, jika tidak mau mengubah perilakunya. Muhtasib dengan memposisikan dirinya sebagai seorang sahabat yang mempunyai kepedulian, secara sengaja mengetuk keras-keras pintu hati klien semacam schok terapi agar pintu hatinya bisa terkuak, karena ketukan halus tidak akan pernah didengar atau bahkan ditertawakan.

\section{d. Bimbingan massal}

Metode ini digunakan dalam kasus pertikaian, yakni bimbingan untuk mendamaikan perselisihan yang sudah terlanjur terbuka, antara buruh dan majikan, peminjam dan yang dipinjami, penjual dan pembeli, perselisihan anak dan ayah, suami dan isteri dsb. Karena persoalannya sudah terbuka maka hisbah yang diberikan juga dilakukan secara terbuka, misalnya dalam forum perdamaian. Sistem hisbah seperti ini berakhir pada akhir masa khalifah Usman bin Affan, selanjutnya pada masa-masa sesudahnya fungsi-fungsi hisbah ini diambil oper oleh aparat pemerintah, dengan nuansa yang berbeda. Pengambil operan hisbah oleh negara nantinya memunculkan istilah wilayat al-Hisbah dalam Fiqh al Siyasah (sistim politik Islam) seperti yang dibahas oleh al Mawardi dalam al Ahkam as Sulthoniyyah (Mursi, 1981: 30-31).

\section{Pengertian Bimbingan dan Konseling Islam}

Pengertian Bimbingan dan Konseling Islam pada dasarnya adalah sama dengan pengertian Bimbingan penyuluhan, hanya saja Bimbingan dan Penyuluhan Islam pada pelaksanaannya berdasarkan atas nilai-nilai keagamaan, sebagaimana yang dipaparkan oleh $\mathrm{H}$. M. Arifin yang dikutip pada buku karangan Imam Sayuti Farid yang berjudul "Pokok-pokok Bahasan Tentang Penyuluhan Agama" menyatakan bahwa Bimbingan dan penyuluhan agama adalah “ segala kegiatan yang dilakukan oleh seseorang dalam memberikan bantuan kepada orang lain, yang mengalami kesulitan-kesulitan rohaniah dalam lingkungan hidupnya, supaya orang tersebut mampu mengatasinya sendiri karena timbul kesadaran atau penyerahan diri terhadap kekuasaan Tuhan Yang Maha Esa, sehingga timbul pada diri pribadinya suatu cahaya harapan, kebahagiaan hidup pada saat sekarang dan masa depannya (Farid, 2007: 25).

Menurut Rasyidan, Bimbingan dan Konseling Agama Sebagai Teknik adalah: "Suatu proses pemberian bantuan kepada individu 
atau kelompok masyarakat, dengan tujuan untuk memfungsikan seoptimal mungkin nilai-nilai keagamaan dalam kebulatan pribadi atau tatanan masyarakat, sehingga dapat memberikan manfaat bagi dirinya dan masyarakat" (Farid, 2007: 26).

Adapun menurut Thohari Musnamar dalam buku "Dasardasar Konseptual Bimbingan dan Konseling Islam" dijelaskan bahwa Bimbingan Islami adalah: Proses pemberian bantuan terhadap individu, agar mampu hidup selaras dengan ketentuan dan petunjuk Allah, sehingga dapat mencapai kebahagiaan hidup di dunia dan di akhirat. Sedangkan Konseling Islami adalah proses pemberian bantuan terhadap individu, agar menyadari kembali akan eksistensinya sebagai makhluk Allah yang seharusnya selaras dengan ketentuan dan petunjuk Allah, sehingga dapat mencapai kebahagiaan di dunia dan di akhirat (Musnamar, 1992: 5).

Dari beberapa definisi yang telah dikemukakan di atas, dapat di garis bawahi bahwa dalam suatu bimbingan penyuluhan Islam, tercakup beberapa unsur, yaitu: (1) Hendaknya ada proses kegiatan (usaha) yang dilakukan secara bertahap, sistematis dan sadar, di dalam memberikan bantuan terhadap orang lain. (2) Bantuan itu diberikan kepada individu atau kelompok, agar ia mampu memfungsikan nilai agama pada dirinya, melalui kesadaran atau potensi dirinya. (3) Bantuan yang diberikan tidak hanya bagi mereka yang bermasalah, tetapi mereka juga yang tidak bermasalah, dengan tujuan agar masalah yang menghinggapi seseorang tidak menjalar kepada orang lain. (4) Bimbingan penyuluhan agama diberikan lebih jauh bertujuan untuk menciptakan situasi dan kondisi masyarakat, yang mampu mengamalkan ajaran agama secara benar dan istiqomah. Sehingga terciptanya masyarakat yang bahagia dan sejahtera baik di dunia maupun di akhirat. Bimbingan dan penyuluhan agama bertujan menciptakan situasi dan kondisi masyarakat yang mengamalkan ajaran agama, dan situasi timbul pancaran kehidupan keagamaan yang sejahtera dan bahagia (Farid, 2007: 12).

Dari uraian di atas penulis menyimpulkan bahwa Bimbingan dan Konseling Islam adalah segala bentuk usaha pemberian bantuan kepada orang lain, baik secara individu maupun secara kelompok, baik yang bermasalah ataupun tidak bermasalah, dengan tujuan agar 


\section{Menuju Bimbingan Konseling Islami}

mereka dapat memfungsikan seoptimal mungkin keimanannya, sehubungan dengan masalah yang dihadapi, terlepas dari masalahnya sehingga mendapatkan kebahagiaan dan kesejahteraan dalam kehidupannya, baik di masa sekarang maupun di masa yang akan datang. Dan ayat-ayat yang berkenaan dengan konseling Islam adalah terdapat dalam QS Al-Isra : 82 yang artinya: "Dan Kami turunkan dari Al Qur'an suatu yang menjadi penwar dan rahmat bagi orang-orang yang beriman dan Al-Qur'an itu tidaklah menambah kepada orang-orang yang lalim selain kerugian".(QS: Al-Isra: 82).

\section{Tujuan Bimbingan dan Konseling Islam}

Dalam kelangsungan perkembangan dan kehidupan manusia, berbagai pelayanan diciptakan dan diselenggarakan. Masing-masing pelayanan ini berguna dan bermanfaat untuk memperlancar dan memberikan dampak positif, konseling Islam ini membantu individu untuk bisa menghadapi masalah sekaligus bisa membantu mengembangkan segi-segi positif yang dimiliki oleh individu. Secara singkat tujuan Konseling Islam dapat dirumuskan sebagai berikut : (1) Tujuan umum Konseling Islam untuk membantu konseli agar dia memiliki pengetahuan tentang posisi dirinya dan memiliki keberanian mengambil keputusan, untuk melakukan suatu perbuatan yang dipandang baik, benar dan bermanfaat, untuk kehidupannya di dunia dan untuk kepentingan akhiratnya. (2) Tujuan khusus bimbingan konseling Islam adalah: (a) Untuk membantu konseli agar tidak menghadapi masalah. (b) Untuk membantu konseli mengatasi masalah yang sedang dihadapinya. (c) Untuk membantu konseli memelihara dan mengembangkan situasi dan kondisi yang baik atau yang telah baik agar tetap baik, sehingga tidak akan menjadi sumber masalah bagi dirinya dan orang lain (Mubarok, 2000: 91).

Adapun yang menjadi tujuan Konseling Islam menurut para ahli lainnya sebagai berikut: Bertujuan memfungsikan seoptimal mungkin nilai-nilai keagamaan dalam kebulatan pribadi atau tantangan masyarakat, sehingga dapat memberikan manfaat bagi dirinya dan masyarakat.

\section{Fungsi Bimbingan dan Konseling Islam}

Dengan memperhatikan tujuan umum dan khusus Bimbingan dan Konseling islam tersebut di atas, dapat dirumuskan fungsi dari 
Bimbingan dan Konseling Islam sebagai berikut: (1) Fungsi preventif; yakni membantu individu menjaga atau mencegah timbulnya masalah bagi dirinya. (2) Fungsi kuratif atau korektif; yakni membantu individu memecahkan masalah yang sedang dihadapi dan dialaminya. (3) Fungsi preservatif; yakni membantu individu menjaga agar situasi dan kondisi yang semula tidak baik (mengandung masalah) yang telah menjadi baik (terpecahkan) itu kembali menjadi tidak baik (menimbulkan masalah kembali). (4) Fungsi development atau pengembangan; yakni membantu individu memelihara dan mengembangkan situasi dan kondisi yang telah baik agar tetap baik atau menjadi lebih baik, sehingga tidak memungkinkannya menjadi sebab munculnya masalah baginya.

\section{Asas-asas Bimbingan Konseling Islam}

Dalam penyelenggaraan layanan bimbingan dan konseling Islam selalu mengacu pada asas-asas bimbingan yang diterapkan dalam penyelenggaraan dan berlandaskan pada al-Quran dan hadits atau sunnah Nabi. Berdasarkan landasan-landasan tersebut dijabarkan asas-asas pelaksanaan bimbingan dan konseling Islam sebagai berikut.

\section{a. Asas-asas kebahagiaan dunia dan akhirat}

Kebahagiaan hidup duniawi, bagi seorang muslim hanya merupakan kebahagiaan yang sifatnya hanya sementara, kebahagiaan akhiratlah yang menjadi tujuan utama. Sebab kebahagiaan akhirat merupakan kebahagiaan abadi, dan bagi semua manusia jika dalam kehidupan dunianya selalu "mengingat Allah" maka kebahagiaan akhiratnya akan tercapai. Firman Allah dalam alQuran surat Ar-Raad ayat 28-29:

Artinya: "(yaitu) orang-orang yang beriman dan hati mereka menjadi tenteram dengan mengingat Allah. Ingatlah, hanya dengan mengingat Allah-lah hati menjadi tenteram. (28) Orangorang yang beriman dan beramal saleh, bagi mereka kebahagiaan dan tempat kembali yang baik (29)". (QS. Ar-Rad: 28-29).

Oleh karena itulah maka Islam mengajarkan hidup dalam keseimbangan, keselarasan dan keserasian antara kehidupan dunia dan akhirat. 


\section{Menuju Bimbingan Konseling Islami}

\section{b. Asas fitrah}

Manusia menurut Islam, dilahirkan dalam atau dengan membawa fitrah, yaitu berbagai kemampuan potensi bawaan dan kecenderungan sebagai muslim atau beragama Islam. Bimbingan dan konseling membantu untuk mengenal dan memahami fitrahnya manakala pernah "tersesat" sehingga akan mampu mencapai kebahagiaan hidup di dunia dan akhirat karena bertingkah laku sesuai dengan fitrahnya. Allah berfirman dalam al-Quran surat ArRum ayat 30 yang artinya :"Maka hadapkanlah wajahmu dengan lurus kepada agama (Allah); (tetaplah atas) fitrah Allah yang telah menciptakan manusia menurut fitrah itu. Tidak ada perubahan pada fitrah Allah. (Itulah) agama yang lurus; tetapi kebanyakan manusia tidak mengetahui" (QS. Ar-Rum: 30).

\section{c. Asas Lillahi Taala}

Bimbingan dan konseling Islam diselenggarakan sematamata karena Allah. Berarti pembimbing melakukan tugasnya dengan penuh keikhlasan, tanpa pamrih. Sementara yang di bimbing menerima atau meminta bimbingan atau konseling dengan ikhlas dan rela. Dan semua yang dilakukan hanya untuk mengabdi pada Allah SWT. Sesuai dengan fungsi dan tugasnya sebagai makhluk Allah SWT. Firman Allah dalam al-Quran surat Al-Anam, ayat 162 yang artinya:"Katakanlah: "Sesungguhnya salat, ibadah, hidup dan matiku hanyalah untuk Allah, Tuhan semesta alam" (QS. Al- Anam: 162)15. Dan dalam surat Az-Dzariyat, ayat 56 yang artinya: "Dan Aku tidak menciptakan jin dan manusia melainkan supaya mereka menyembahKu" (QS. Az-Dzariyat: 56).

\section{d. Asas bimbingan seumur hidup}

Dalam kehidupan manusia akan menjumpai berbagai kesulitan dan kesusahan. Oleh karena itulah maka bimbingan dan konseling Islam diperlukan selama hayat masih dikandung badan. Kesepanjang hayatan bimbingan dan konseling ini, selain dilihat dari kenyataan hidup, dapat pula dilihat dari sudut pendidikan, bimbingan dan konseling merupakan bagian dari pendidikan. Pendidikan sendiri berasaskan pendidikan seumur hidup, karena belajar menurut Islam wajib dilakukan oleh semua orang Islam tanpa membedakan usia. 


\section{e. Asas kesatuan jasmaniah-rohaniah}

Manusia itu dalam hidupnya di dunia merupakan satu kesatuan jasmaniah-rohaniah. Bimbingan dan konseling Islam memperlakukan konselinya sebagai makhluk jasmaniah-rohaniah, tidak memandangnya sebagai makhluk biologis semata. Bimbingan konseling Islam membantu individu untuk hidup dalam keseimbangan jasmaniah dan rohaniah. Allah telah memberikan contoh dengan kasus yang digambarkan pada al- Quran surat AlBaqarah, ayat 187:

Artinya: "Dihalalkan bagi kamu pada malam hari bulan Puasa bercampur dengan istri-istri kamu; mereka itu adalah pakaian bagimu, dan kamu pun adalah pakaian bagi mereka. Allah mengetahui bahwasanya kamu tidak dapat menahan nafsumu, karena itu Allah mengampuni kamu dan memberi maaf kepadamu. Maka sekarang campurilah mereka dan carilah apa yang telah ditetapkan Allah untukmu, dan makan minumlah hingga terang bagimu benang putih dari benang hitam, yaitu fajar. Kemudian sempurnakanlah puasa itu sampai (datang) malam, (tetapi) janganlah kamu campuri mereka itu, sedang kamu beri'tikaf dalam mesjid. Itulah larangan Allah, maka janganlah kamu mendekatinya. Demikianlah Allah menerangkan ayatayat- Nya kepada manusia, supaya mereka bertakwa" (QS. AlBaqarah: 187).

\section{f. Asas keseimbangan rohaniah}

Bimbingan dan konseling Islam menyadari keadaan kodrati manusia tersebut, dan dengan berpijak pada fatwa-fatwa Tuhan serta hadits Nabi, membantu konseli memperoleh keseimbangan diri dalam segi mental rohaniah. Allah berfirman dalam surat Al- Araf ayat 179:

Artinya: "Dan sesungguhnya Kami jadikan untuk isi neraka Jahanam kebanyakan dari jin dan manusia, mereka mempunyai hati, tetapi tidak dipergunakannya untuk memahami (ayat-ayat Allah) dan mereka mempunyai mata (tetapi) tidak dipergunakannya untuk melihat (tanda-tanda kekuasaan Allah), dan mereka mempunyai telinga (tetapi) tidak dipergunakannya untuk mendengar (ayat-ayat Allah). Mereka itu sebagai binatang ternak, bahkan mereka lebih sesat lagi. Mereka itulah orangorang yang lalai". (QS. Al-Araf: 179). 


\section{Menuju Bimbingan Konseling Islami}

Orang-orang yang dibimbing dan diajak untuk mempergunakan semua kemampuan rohaniah potensialnya, bukan cuma mengikuti hawa nafsu (perasaan dan kehendak) semata.

\section{g. Asas kemajuan individu}

Bimbingan dan konseling Islam, berlangsung pada citra manusia menurut Islam, memandang seorang individu merupakan individu yang mempunyai hak, mempunyai perbedaan dari yang lain dan mempunyai kemerdekaan pribadi. Mengenai perbedaan individual bisa dilihat dari al-Quran surat Al-Qomar, ayat 49 yang artinya: "Sesungguhnya Kami menciptakan segala sesuatu menurut ukuran". (QS. Al-Qomar: 49).

\section{h. Asas sosialitas manusia}

Dalam Bimbingan dan konseling Islam, sosialitas manusia diakui dengan memperhatikan hak individu. Manusia merupakan makhluk sosial hal ini dapat diperhatikan dalam bimbingan dan konseling Islam. Pergaulan, cinta, kasih, rasa aman, penghargaan terhadap diri sendiri, orang lain dapat memiliki dan dimiliki.

\section{i. Asas kekhalifahan manusia}

Manusia menurut Islam, diberi kedudukan yang tinggi sekaligus tanggung jawab yang besar yaitu sebagai pengelola alam semesta (khalifatullah fil ard). Dengan kata lain, manusia dipandang sebagai makhluk berbudaya yang mengelola alam sekitar sebaikbaiknya. Allah berfirman dalam surat Faathir ayat 39:

Artinya:"Dia-lah yang menjadikan kamu khalifah-khalifah di muka bumi. Barang siapa yang kafir, maka (akibat) kekafirannya menimpa dirinya sendiri. Dan kekafiran orang-orang yang kafir itu tidak lain hanyalah akan menambah kemurkaan pada sisi Tuhannya dan kekafiran orang-orang yang kafir itu tidak lain hanyalah akan menambah kerugian mereka belaka”. (QS. Al- Fatir: 39).

Kedudukan manusia sebagai khalifah itu dalam keseimbangan dengan kedudukannya sebagai makhluk Allah yang harus mengabdi pada-Nya. Dan jika memiliki kedudukan tidak akan memperturutkan hawa nafsu belaka.

\section{j. Asas keselarasan dan keadilan}

Islam menghendaki keharmonisan, keselarasan, keseimbangan, keserasian dalam segala hal. Islam menghendaki 
manusia berlaku "adil" terhadap hak dirinya sendiri, hak orang lain, hak alam semesta dan juga hak Tuhan.

\section{k. Asas pembinaan akhlaqul-karimah}

Manusia menurut pandangan Islam, memiliki sifat-sifat yang baik (mulia). Sifat yang baik merupakan sifat yang dikembangkan oleh bimbingan dan konseling Islam. Bimbingan dan konseling Islam membantu konseli atau yang dibimbing, memelihara, mengembangkan, menyempurnakan sifat-sifat yang sejalan dengan tugas dan fungsi Rasulullah SAW. Allah berfirman dalam surat AlAhzab ayat 21 yang artinya: "Sesungguhnya telah ada pada (diri) Rasulullah itu suri teladan yang baik bagimu (yaitu) bagi orang yang mengharap (rahmat) Allah dan (kedatangan) hari kiamat dan dia banyak menyebut Allah". (QS. Al-Ahzab: 21).

\section{l. Asas kasih sayang}

Setiap manusia memerlukan cinta dan rasa sayang dari orang lain. Rasa kasih sayang ini dapat mengalahkan dan menundukkan banyak hal. Bimbingan dan konseling Islam dilakukan dengan berlandaskan kasih dan sayang, sebab hanya dengan kasih sayanglah bimbingan dan konseling akan berhasil.

\section{m.Asas saling menghargai dan menghormati}

Dalam bimbingan dan konseling Islam kedudukan pembimbing atau konselor dengan yang dibimbing atau konseli itu sama sederajat. Namun ada perbedaan yang terletak pada fungsi yakni pihak satu memberikan bantuan dan yang satu menerima, hubungan antara konselor dan konseli merupakan hubungan saling menghormati sesuai dengan kedudukan masing-masing sebagai makhluk Allah.

Konselor diberi kehormatan oleh konseli karena dirinya dianggap mampu memberikan bantuan mengatasi masalahnya. Sementara konseli diberi kehormatan atau dihargai oleh konselor dengan cara dia bersedia untuk diberikan bantuan atau dibimbing seperti kasus yang relatif sederhana, Allah berfirman dalam al-Quran surat An-Nisa ayat 86 yang artinya: "Apabila kamu dihormati dengan suatu penghormatan, maka balaslah penghormatan itu dengan yang lebih baik, atau balaslah (dengan yang serupa). Sesungguhnya Allah memperhitungkan segala sesuatu". (QS. An-Nisa: 86). 


\section{Menuju Bimbingan Konseling Islami}

\section{n. Asas musyawarah}

Bimbingan dan konseling Islam dilakukan dengan asas musyawarah. Maksudnya antara konselor dan konseli terjadi dialog yang baik, tidak ada pemaksaan, tidak ada perasaan tertekan, semua ini berjalan dengan baik.

\section{o. Asas keahlian}

Bimbingan dan konseling Islam dilakukan oleh orang-orang yang memang memiliki kemampuan dan keahlian dalam metodologi dan teknik-teknik bimbingan dan konseling (Faqih, 2001: 22-35).

\section{Kesimpulan}

Dari beberapa uraian sebelumnya dapat dikemukakan halhal berikut ini: Pertama, Pada dataran teori, psikologi konseling memiliki empat grand theories, yaitu psikoanalisis, behavioristik, humanistik dan transpersonal. Kedua, Konseling Islam akan bergerak menjadi mazhab kelima dari disiplin psikologi dengan cara mengembalikan paradigma ilmuwan kepada orientasi dunia dan akhirat. Ketiga, Fitrah manusia sebagai makhluk ciptaan Allah SWT ialah manusia diciptakan mempunyai naluri beragama yaitu agama tauhid. Keempat, perlu ditekankan kajian keagamaan, baik hal itu berasal dari perspektif Indigenous Counseling yang cross cultural dan mengungkap variabel budaya lokal maupun Konseling Agama itu sendiri terhadap pembentukan karakter individu. Kelima, konseling agama yang dijumpai pada zaman klasik Islam dikenal dengan nama hisbah, atau ihtisab, konselornya disebut muhtasib, dan klien dinamakan muhtasab'alaih. Keenam, Bimbingan Konseling Islami adalah: Proses pemberian bantuan terhadap individu sesuai asas yang pelaksanaan, agar mampu hidup selaras dengan ketentuan dan petunjuk Allah, sehingga dapat mencapai kebahagiaan hidup di dunia dan di akhirat 


\section{Hasan Bastomi}

\section{Daftar Pustaka}

Ancok, Djamaluddin. "Kata Pengantar" dalam Fuad Nashori (ed.). 1996. Membangun Paradigma Psikologi Islami, Yogyakarta: Sipress

Badri, Malik B. 1994. Dilema Psikolog Muslim, Terj. Siti Zaenab Lutfiati, Jakarta:Pustaka Firdaus

Bastaman, Hanna Djumhana. 2001. Integrasi Psikologi dengan Islam, Yogyakarta: Pustaka Pelajar

Faqih, Ainur Rahim. 2001. Bimbingan dan Konseling dalam Islam Yogyakarta : UII Press

Farid, Imam Sayuti. 2007. Pokok-pokok Bahasan tentang Bimbingan Penyuluhan Agama sebagai Tenik Dakwah, Jakarta: Bulan Bintang

Hidayat, Bahril. 2014. Psikologi Islam, Riau: Psikologi UIN Sultan syarif kasim

Jalaluddin. 2010. Psikologi Agama, Jakarta: PT RajaGrafindo Persada

Khan, Inayat. 2000. Dimensi Spiritual Psikologi, terj. Andi Haryadi, Jakarta: Pustaka Hidayah.

Lessin, Doris dalam pengantar terhadap karya Idries Shah, 2002. Learning How To Learn: Psychology And Spirituality In The Sufi Way, terj. Rahmani Astuti, Jakarta: Pustaka Hidayah

Mubarok, Achmad. 2000. Konseling Agama Teori dan Kasus Jakarta: Bina Rena Pariwara

Mursi, Kamal Ibrahim. 1981. Al-Tifl Ghayr Al-Adi Min Al-Nahiyah AlDhihniyah, Cairo: Dar al-Nahdah al-Arabiyah

Musnamar, Tohari. 1992. Dasar-dasar Konseptual Bimbingan dan Konseling Islami, Jakarta: UII Press

Mutiara S, Panggabean. 2009. Manajemen Sumber Daya Manusia, Bogor, Penerbit: Ghalia Indonesia

Nashori, Fuad. 2010. Agenda Psikologi Islami, Yogyakarta: Pustaka Pelajar

Nurbakhsy, Javad. 1992. Psychology of Sufism, Teheran: Publication KNP

Raji, Ismail. 1982. Islamization of Knowledge: General Principles and Work Plan. New York: International Institute of Islamic Thought Subandi, M. A. 2002. Psikoterapi Pendekatan Konvensional Dan Kontemporer, Yogyakarta: Pustaka Pelajar 


\section{Menuju Bimbingan Konseling Islami}

Subandi, M.A. Reposisi Psikologi Islam, Fakultas Psikologi UGM, Disampaikan pada Temu Ilmiah Nasional I Psikologi Islam, Yogyakarta, 24 September 200 